\title{
Amphibia, Anura, Hylidae, Scinax cardosoi (Carvalho-e- Silva and Peixoto, 1991): Distribution extension
}

\author{
Antônio Meira Linares ${ }^{1 *}$, Marcelo Henrique de Oliveira Batemarque ${ }^{2}$, Humberto Espírito Santo de \\ Mello $^{3}$ and Luciana Barreto Nascimento ${ }^{1,4}$ \\ 1 Programa de Pós Graduação em Zoologia de Vertebrados, Pontifícia Universidade Católica de Minas Gerais. Avenida Dom José Gaspar, 290. \\ CEP 30535-610. Belo Horizonte, MG, Brasil. \\ 2 Rua Ourinhos, 24. CEP 30882-540. Belo Horizonte, MG, Brasil. \\ 3 Fundação Zoo-Botânica de Belo Horizonte. CEP 31365-450. Belo Horizonte, MG, Brasil. \\ 4 Museu de Ciências Naturais, Pontifícia Universidade Católica de Minas Gerais. CEP 30535-901. Belo Horizonte, MG, Brasil. \\ * Corresponding author. E-mail: bioantonio1@yahoo.com.br
}

\begin{abstract}
We report the geographical distribution extension of Scinax cardosoi to the central region of the State of Minas Gerais, at Espinhaço Mountain Range. During field work in November and December 2009 at the Municipality of Conceição do Mato Dentro, we collected some S. cardosoi specimens associated to temporary ponds, near to permanent streams in open and forested areas, in a transitional area of Atlantic Forest and Cerrado domains. The present record extends the distribution of $S$. cardosoi ca. $333 \mathrm{~km}$ from the other record of this species in the State of Minas Gerais.
\end{abstract}

The genus Scinax Wagler, 1830 currently encompasses 99 recognized species, with distribution in eastern and southern Mexico to Argentina and Uruguay, and also in the islands of Trinidad and Tobago and St. Lucia (Frost 2010; Nunes et al. 2010). Scinax cardosoi (Carvalho-e-Silva and Peixoto, 1991) is associated to the Scinax ruber clade and unassigned to any group by Faivovich et al. (2005). This species is characterized by small size, with females much bigger than males, transverse dark bars on the dorsal surface of limbs, and longitudinal dark stripes on the dorsal surface of body (Carvalho-e-Silva and Peixoto 1991). Although this species is not thought to be common, with decreasing populations, it is currently classified as Least Concern according to the IUCN Red List (Carvalho-eSilva and Caramaschi 2004).

The type specimens of $S$. cardosoi (10 males and one female) were collected at Vale da Revolta, in the Municipality of Teresópolis, state of Rio de Janeiro, and in the municipality of Domingos Martins, state of Espírito Santo, Brazil (Carvalho-e-Silva and Peixoto 1991). Besides these localities, this species is also known from Serra da Mantiqueira and Serra do Mar mountains ranges at state of Rio de Janeiro (Carvalho-e-Silva and Caramaschi 2004). Recently, this species was first recorded at southern state of Minas Gerais, in the Reserva Particular do Patrimônio Natural (RPPN) Ovídio Antônio Pires, municipalities of Santa Rita da Jacutinga and Bom Jardim de Minas (Pinto et al. 2009). Here we report the geographical distribution extension of $S$. cardosoi to the Espinhaço Mountain Range, on the central region of the state of Minas Gerais.

During field work on November and December 2009, AML and MHOB observed, recorded, and collected (permits \#154/2009 NUFAS/MG, Instituto Brasileiro do Meio Ambiente e dos Recursos Naturais Renováveis - IBAMA, and \#21185-1, Instituto Chico Mendes de Conservação da Biodiversidade - ICMBio) several individuals of $S$. cardosoi (Figure 1) in a few localities (Table 1) at Serra da Ferrugem

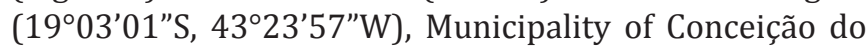

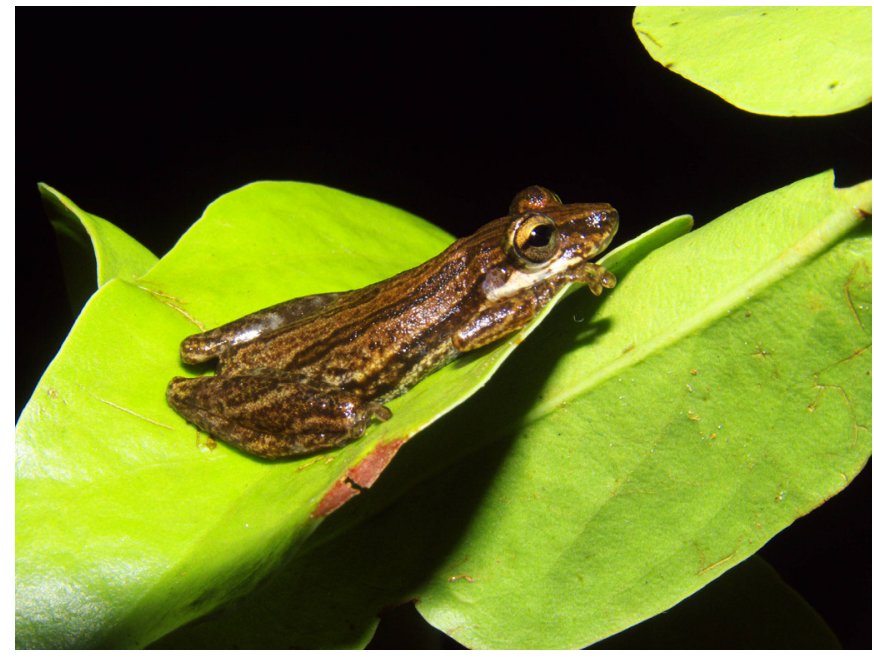

Figure 1. Adult female of Scinax cardosoi (MCNAM 14509), collected at municipality of Conceição do Mato Dentro, state of Minas Gerais, Brazil. Photo by Antônio Linares.

Mato Dentro, between 764 and $926 \mathrm{~m}$ in altitude. The area is in the transition between the Atlantic Forest and Cerrado domains, with open and forested sites. Scinax cardosoi was found in both phytophysiognomies (Table 1), associated to temporary ponds, near to permanent streams. This species is known as a slow-flowing permanent streams breeder (Carvalho-e-Silva and Caramaschi 2004), but we also found it reproducing in temporary ponds. The present record extends the distribution of $S$. cardosoi ca. $345 \mathrm{~km}$ northwest from the type locality at Vale da Revolta, in the municipality of Teresópolis, $319 \mathrm{~km}$ from the municipality of Domingos Martins, and $333 \mathrm{~km}$ from the first record of this species in state of Minas Gerais, at the municipalities of Santa Rita da Jacutinga and Bom Jardim de Minas (Figure 2). This was the first record for the species in anthropogenic habitat (see Table 1) and also the first record outside protected areas (Carvalho-e-Silva and Caramaschi 2004; Pinto et al. 2009). This record reinforces the argument of how poor is the current knowledge of the distribution and 
TABLE 1. Description of the sample sites where Scinax cardosoi was found at municipality of Conceição do Mato Dentro, with respective geographic coordinates and altitude.

\begin{tabular}{|c|c|c|c|}
\hline SITE & $\begin{array}{l}\text { GEOGRAPHIC } \\
\text { COORDINATES }\end{array}$ & $\begin{array}{l}\text { ALTITUDE } \\
\text { (M) }\end{array}$ & DESCRIPTION OF SAMPLE SITE \\
\hline 1 & $19^{\circ} 03^{\prime} 01^{\prime \prime} \mathrm{S}, 43^{\circ} 23^{\prime} 57^{\prime \prime} \mathrm{W}$ & 926 & Permanent stream with sandy bottom, in gallery forest. \\
\hline 2 & $19^{\circ} 01^{\prime} 39^{\prime \prime} \mathrm{S}, 43^{\circ} 24^{\prime} 03^{\prime \prime} \mathrm{W}$ & 846 & Permanent stream with sandy / rocky bottom, with a temporary pond, in gallery forest. \\
\hline 3 & $19^{\circ} 03^{\prime} 46^{\prime \prime} \mathrm{S}, 43^{\circ} 24^{\prime} 45^{\prime \prime} \mathrm{W}$ & 791 & Permanent stream with rocky bottom, in anthropogenic area. \\
\hline 4 & $19^{\circ} 03^{\prime} 48^{\prime \prime} \mathrm{S}, 43^{\circ} 24^{\prime} 21^{\prime \prime} \mathrm{W}$ & 764 & $\begin{array}{l}\text { Permanent stream with rocky bottom, in open anthropogenic area with temporary } \\
\text { marshes. }\end{array}$ \\
\hline
\end{tabular}

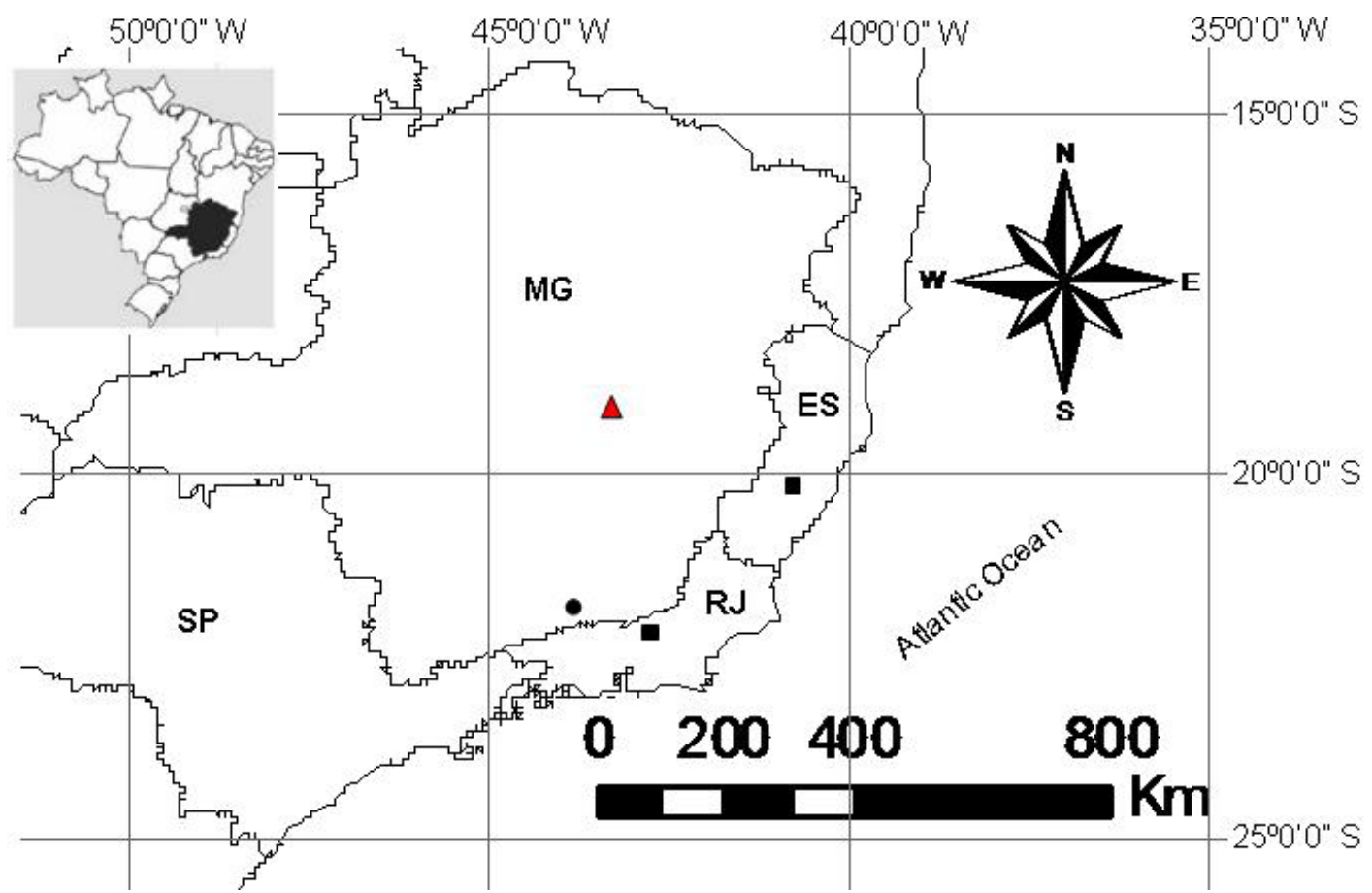

FIGURE 2. Distribution map of Scinax cardosoi. Squares: original localities; Circle: first record for the species in the state of Minas Gerais (Pinto et al. 2009); Red triangle: new record. MG = state of Minas Gerais; ES = state of Espírito Santo; RJ = state of Rio de Janeiro; SP = state of São Paulo.

abundance of the anuran fauna of Brazil (Pimenta et al. 2005; Marques et al. 2006; Araujo et al. 2007).

The vouchers (SVL male $=20.9 \pm 0.74 \mathrm{~mm}, \mathrm{n}=$ 9; SVL female $=26.1 \mathrm{~mm}, \mathrm{n}=1$ ) were housed in the herpetological collection of Museu de Ciências Naturais of Pontifícia Universidade Católica de Minas Gerais (MCNAM 14505-14509) and in the herpetological collection of Universidade Federal de Minas Gerais (UFMG Amphibia 4196-4200). The species identification was confirmed by comparison with specimens housed at Museu de Ciências Naturais and by analyses of advertisement calls.

ACKNOWLEDGMENTS: We thank Lume Estratégia Ambiental for logistical support to AML, MHOB, and HESM; to the Instituto Brasileiro do Meio Ambiente e dos Recursos Naturais Renováveis (IBAMA) for collection permits; to the Fundação de Amparo à Pesquisa do Estado de Minas Gerais (FAPEMIG) for financial support to LBN; and two anonymous referees for valuable suggestions.

\section{LITERATURE CiTED}

Araujo, C.O., T.H. Condez and C.F.B. Haddad. 2007. Amphibia, Anura, Phyllomedusa ayeaye (B. Lutz, 1966): distribution extension, new state record, and geographic distribution map. Check List 3(2): 156158.

Carvalho-e-Silva, S.P. and O.L. Peixoto. 1991. Duas novas espécies de Ololygon para os estados do Rio de Janeiro e Espírito Santo (Amphibia, Anura, Hylidae). Revista Brasileira de Biologia 51(1): 263-270.
Carvalho-e-Silva, S.P. and U. Caramaschi. 2004. Scinax cardosoi. In IUCN 2010. IUCN Red List of Threatened Species. Version 2010.2. Available at www.iucnredlist.org. Captured on 20 August 2010.

Faivovich, J., P.C.A Garcia, C.F.B. Haddad, D.R. Frost, J.A. Campbell and W.C. Wheeler. 2005. Systematic review of the frog family Hylidae, with special reference to Hylinae: phylogenetic analysis and taxonomic revision. Bulletin of the American Museum of Natural History 294: $1-240$.

Frost, D.R. 2010. Amphibian Species of the World: an Online Reference. Version 5.4 (8 April, 2010). Electronic Database accessible at http:// research.amnh.org/vz/herpetology/amphibia/. Captured on 27 July 2010.

Marques, R.M., P.F. Colas-Rosas, L.T. Toledo and C.F.B. Haddad. 2006. Amphibia, Anura, Bufonidae, Melanophryniscus moreirae: distribution extension. Check List 2(1): 68-69.

Nunes, I., R.R. Carvalho Jr. and E.G. Pereira. 2010. A new species of Scinax Wagler (Anura: Hylidae) from Cerrado of Brazil. Zootaxa 2514: 2434 .

Pimenta, B.V.S., C.F.B. Haddad, L.B. Nascimento, C.A.G. Cruz and J.P. Pombal Jr. 2005. Comment on "Status and trends of amphibian declines and extinctions worldwide". Science 309: 1999.

Pinto, F.C.S., R.A.R Campos, F.S. Braga, F.N.S. Queirós and L.B. Nascimento. 2009. Amphibia, Anura, Hylidae, Scinax cardosoi Carvalho-e-Silva and Peixoto, 1991: distribution extension and new state records. Check List 5(4): 866-868.

RECEIVED: October 2010

LAST REVISED: June 2011

ACCEPTED: June 2011

PuBLISHED ONLINE: July 2011

EDITORIAL RESPONSIBILITY: Juliana Zina 